\title{
5, 7-Dihalo-8-quinolinol complex inhibits growth of ovarian cancer cells via the downregulation of expression of Wip1
}

\author{
Rao Zhiwei ${ }^{1}$, Xia Songbai ${ }^{1}$, Han $\mathbf{Q i}^{2 *}$ \\ ${ }^{1}$ Department of Pharmacy, ${ }^{2}$ Department of Oncology, Xianning Central Hospital, Hubei Province, The First Affiliated Hospital, \\ Hubei University of Science and Technology, Xianning 437100, China \\ *For correspondence: Email: HeribertoVelasquezeis@yahoo.com; Tel/Fax: 0086-18062680913

\begin{abstract}
Purpose: To assess the cytotoxic effect of 5, 7-dihalo-8-quinolinol complex (DHQ) on ovarian cancer cells, and the mechanism of action involved.

Methods: DHQ-mediated changes in cell viability were determined using MTT assay, while apoptosis was analyzed with flow cytometry. The effect of $D H Q$ on cell migration was determined using inverted microscopy, while its effect on invasiveness was assessed with Giemsa dyeing. FACS Calibur instrumentation was employed for analyzing the effect of DHQ on the cell cycle. The protein expressions of Wip1 and P53 were assayed by western blotting.

Results: $D H Q$ induced cytotoxicity against $A 2780$ and OVCAR 3 cells in the concentration range of $0.25-12 \mu M(p<0.05)$. In A2780 and OVCAR 3 cells, treatment with $12 \mu M D H Q$ resulted in 69.34 and $65.46 \%$ apoptosis, respectively. The migratory potential and invasiveness of A2780 and OVCAR3 cells were significantly decreased by $12 \mu M D H Q$, relative to untreated cells $(p<0.05)$. Moreover, treatment with $12 \mu \mathrm{MDHQ}$ arrested cell cycle at G1/G0 phase in A2780 and OVCAR3 cells, but downregulated the protein expressions of Wip1 expression in A2780 and OVCAR3 cells.

Conclusion: $D H Q$ exerts cytotoxic effect on ovarian cancer cell growth via arrest of cell cycle and activation of apoptosis. Moreover, DHQ inhibits the migratory and invasive abilities of the cells. Thus, $D H Q$ is a potential drug candidate for the management of ovarian cancer.
\end{abstract}

Keywords: 5,7-Dihalo-8-quinolinol complex, Ovarian cancer, Cytotoxicity, Apoptosis, Invasiveness, Migration, Cell cycle

\begin{abstract}
This is an Open Access article that uses a fund-ing model which does not charge readers or their institutions for access and distributed under the terms of the Creative Commons Attribution License (http://creativecommons.org/licenses/by/4.0) and the Budapest Open Access Initiative (http://www.budapestopenaccessinitiative.org/read), which permit unrestricted use, distribution, and reproduction in any medium, provided the original work is properly credited.

Tropical Journal of Pharmaceutical Research is indexed by Science Citation Index (SciSearch), Scopus, International Pharmaceutical Abstract, Chemical Abstracts, Embase, Index Copernicus, EBSCO, African Index Medicus, JournalSeek, Journal Citation Reports/Science Edition, Directory of Open Access Journals (DOAJ), African Journal Online, Bioline International, Open-J-Gate and Pharmacy Abstracts
\end{abstract}

\section{INTRODUCTION}

Ovarian carcinoma is one of the most lethal malignancies and the $5^{\text {th }}$ highest cause of cancer-related deaths in the United States [1]. The high mortality of ovarian cancer is associated with resistance to chemotherapy, tumor recurrence and elevated metastatic potential [2]. Moreover, up to $75 \%$ of ovary cancer is diagnosed at the advanced stage, resulting in high mortality and poor prognosis [3]. Slowly-growing ovarian cancers detected at initial stage are known as type I tumors [4]. In contrast, the type II cancers which are highly aggressive, are detected at advanced stage and they grow very rapidly [4]. 
The common treatment for ovarian cancer is surgical resection aimed at decreasing the cancerous cells, and administration of taxol/platinum-containing chemotherapeutic agents. Although about $80 \%$ of ovarian cancer patients show good responses initially, tumor relapse has been reported in more than $50 \%$ of cases $[4,5]$. Patients who develop resistance to platinum or taxol are given more potent drugs, an example of which is topotecan [5]. Most ovarian cancer cells escape chemotherapeutic drugs by remaining in the non-proliferating and dormant stage [6].

These dormant cancerous cells start proliferating when the effect of the chemotherapeutic agent subsides, leading to tumor relapse and failure of therapeutic strategy [6]. Thus, there is a need for novel and effective therapeutic agents for treatment of ovarian cancer.

Induction of wild-type p53-induced phosphatase (Wip1) is generally observed in cells in the presence of ionizing radiations [7]. The Wip1 encodes a protein known as protein phosphatase magnesium-dependent $1 \delta$ located in 17q22/24 region of chromosome in humans [7]. It belongs to the phosphatase type-2C (PP2C) family of proteins. Studies have reported Wip1 overexpression in different types of cancers and its association with carcinoma growth $[8,9]$. Therefore, Wip1 is considered a biomarker in various cancers, and it may act as target for therapeutic agents [8, 9]. Potent anti-tumor complexes were discovered by linking metal ions to organic compounds isolated from diversity of sources [10]. The improved pharmacological potential and limited side effects have encouraged clinicians to investigate the antitumor properties of other organo-metallic complexes [11]. This has led to identification of metal complexes which are effective in the inhibition of tumor growth at low doses, with minimum harmful effects on normal cells $[12,13]$.

In the present study, the anti-cancer effect of $\mathrm{DHQ}$ on ovarian cancer cells was investigated.

\section{EXPERIMENTAL}

\section{Cell lines and culture conditions}

The A2780 and OVCAR 3 ovarian carcinoma cell lines were provided by the Cell Resource Center of Peking Union Medical College (Beijing, China). The cell lines were cultured for $24 \mathrm{~h}$ under $5 \%$ $\mathrm{CO}_{2}$ atmosphere in DMEM at $37^{\circ} \mathrm{C}$. The medium contained $10 \%$ FBS, penicillin $(100 \mathrm{U} / \mathrm{mL})$ and streptomycin $(100 \mu \mathrm{g} / \mathrm{mL})$.

\section{Assay of cell viability}

The effect of DHQ on cell viability was determined using MTT assay. The cells were seeded in 96-well plates, each at a density of $1 \mathrm{x}$ $10^{6}$ cells/well, and cultured at $37^{\circ} \mathrm{C}$ for $24 \mathrm{~h}$. Then, DHQ was added to separate wells at concentrations of $0.25,0.5,1.0,2.0,4.0,8.0$ and $12 \mu \mathrm{M}$, followed by incubation for $48 \mathrm{~h}$. Thereafter, MTT solution $(5 \mathrm{mg} / \mathrm{mL})$ was added to the well plates, and incubation was continued for $4 \mathrm{~h}$ under similar conditions.

Following decantation of medium, DMSO (100 $\mu \mathrm{L}$ ) was added to each well to solubilize the resultant formazan crystals. The absorbance of each well was read in an ELISA plate reader at $568 \mathrm{~nm}$, and the readings were used to estimate the effect of $\mathrm{DHQ}$ on cell viability, relative to untreated cells.

\section{Apoptosis assay}

Cells treated with $12 \mu \mathrm{M} \mathrm{DHQ}$ and untreated cells were harvested, rinsed in PBS and subsequently fixed in $70 \%$ ethyl alcohol. Cells (at a density $1 \times 10^{5}$ cells $/ \mathrm{mL}$ ) were treated for 20 min with Annexin V-FITC $(20 \mu \mathrm{L})$ at room temperature in the dark. Then, the cells were suspended in binding Buffer-1X and treated with propidium iodide for $4 \mathrm{~min}$, also in the dark. Thereafter, cell apoptosis was analyzed in a flow cytometer (FACSCalibur, BD) with FlowJo software (FlowJo, BD).

\section{Wound healing assay}

The cells were seeded in6-well plates at a density of $1 \times 10^{5}$ cells/well, and maintained at 37 ${ }^{\circ} \mathrm{C}$ until $100 \%$ confluent cellular monolayers were obtained. A24-h cellular starvation was followed by creating a wound on the center of wells using a $100-\mathrm{ml}$ pipette tip. The cells were treated with $12 \mu \mathrm{M} D \mathrm{DHQ}$ or normal saline for $48 \mathrm{~h}$, followed by washing with PBS at $37^{\circ} \mathrm{C}$. Thereafter, the cells were fixed in $3.5 \%$ ethyl alcohol and subsequentlydyedwith $2 \%$ crystal violet stain for $25 \mathrm{~min}$. Cell migration was visualized and analyzed using a microscope (Nikon Corporation) in5 randomly-selected fields.

\section{Invasion assays}

The effect of DHQ on cellular invasiveness was determined in 24-well Transwell chambers $(8-\mu \mathrm{m}$ pore size Y). Matrigel ( $85 \mu \mathrm{g} / \mathrm{ml}$; BD Biosciences) was applied onto the upper membrane surface and kept overnight at $37^{\circ} \mathrm{C}$. The cells were distributed in the upper chamber at a concentration of $1 \times 10^{5}$ cells $/ \mathrm{mL}$ in $320 \mu$ of 
DMEM containing $10 \%$ FBS, while $550 \mu \mathrm{L}$ of DMEM containing $5 \%$ FBS was put in the lower compartment. Then, the cells were cultured at 37 ${ }^{\circ} \mathrm{C}$ in an atmosphere of $5 \% \mathrm{CO}_{2}$ and $95 \%$ air for $48 \mathrm{~h}$. The invaded cells were subjected to Giemsa dyeing (Sigma, USA), followed by analysis under a 200X phase-contrast microscope.

\section{Cell cycle analysis}

The cells were seeded at a density of $2 \times 10^{6}$ cells/well in $60-\mathrm{mm}$ plates, and were treated with $12 \mu \mathrm{M} \mathrm{DHQ}$ or normal saline at $37^{\circ} \mathrm{C}$ for $48 \mathrm{~h}$. Trypsinization and washing in PBS were followed by fixing in $70 \%$ ethyl alcohol overnight at $37^{\circ} \mathrm{C}$. Then, the cells were treated with RNase A $(20$ $\mu \mathrm{g} / \mathrm{mL})$, and stained with $\mathrm{PI}(10 \mu \mathrm{g} / \mathrm{mL})$ at $37^{\circ} \mathrm{C}$. Thereafter, the distribution of cellular DNA content was determined using FACSCalibur instrumentation (BD Biosciences, San Jose, CA, USA).

\section{Western blot analysis}

Cells treated with $12 \mu \mathrm{M} \mathrm{DHQ}$ and untreated cells were harvested, rinsed in ice-cold PBS and subsequently subjected to lysis using RIPA buffer containing $\mathrm{PhCH}_{2} \mathrm{SO}_{2} \mathrm{~F}$ at $4^{\circ} \mathrm{C}$ for $30 \mathrm{~min}$. The lysate was centrifuged at $12,000 \times \mathrm{g}$ for 15 $\min$ at $4^{\circ} \mathrm{C}$, and the protein content of the supernatant was estimated using BCA protein assay kit. Then, equal amounts of proteins were separated on $10 \%$ SDS PAGE and transferred to PVDF membranes which were blocked by treatment with non-fat dry milk $(5 \%)$ for $2 \mathrm{~h}$. Protein probing was done on incubation of the membranes with primary antibodies against Wip1, P53 and GAPDH overnight at $4{ }^{\circ} \mathrm{C}$.

Then, the membranes were washed with PBS, followed by incubation with horse radish peroxidase-conjugated goat anti-rabbit secondary antibody for $1 \mathrm{~h}$ at room temperature. The protein bands were detected using Bio-Rad ChemiDoc $^{\mathrm{TM}}$ (Bio-Rad Laboratories, Co., Ltd, Hercules, CA, USA).

\section{Statistical analysis}

Data are presented as mean $\pm \mathrm{SD}$; differences between and amongst various groups were determined using Student $t$-test and one-way analysis of variance (ANOVA), respectively. Statistical analysis was carried out with GraphPad Prism-7 software (GraphPad Software Inc., La Jolla, CA, USA). Differences were taken as statistically significant at $p<0.05$.

\section{RESULTS}

\section{Inhibitory effect of DHQ on the viability of A2780 and OVCAR 3 cells}

The cytotoxic effects of DHQ on $\mathrm{A} 2780$ and OVCAR 3 cells were measured at different durations using MTT assay. The viability of A2780 and OVCAR 3 cells were reduced to 47 and $51 \%$, respectively, on treatment with $12 \mu \mathrm{M}$ $\mathrm{DHQ}$ at $24 \mathrm{~h}$ (Figure $1 \mathrm{~A}$ ). Treatment with $12 \mu \mathrm{M}$ DHQ for $48 \mathrm{~h}$ suppressed viabilities of A2780 and OVCAR cells to 20 and $23 \%$, respectively (Figure $1 \mathrm{~B}$ ). The changes in cellular viabilities due to $12 \mu \mathrm{M} \mathrm{DHQ}$ at $48 \mathrm{~h}$ were also determined using inverted microscopy (Figure $1 \mathrm{C}$ ). There were clear reductions in viabilities of the two cells treated with $12 \mu \mathrm{M} \mathrm{DHQ}$ for $48 \mathrm{~h}$.

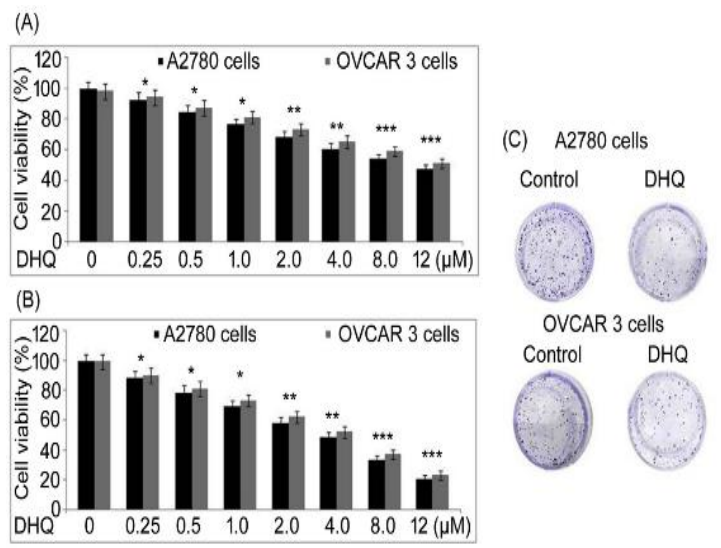

Figure 1: Effect of DHQ on cell viability. (A) Treatment of cells with $0.25,0.5,1.0,2.0,4.0,8.0$ and $12 \mu \mathrm{M}$ $\mathrm{DHQ}$ for $24 \mathrm{~h}$ was followed by determination of viability. (B) Exposure of the cells to $0.25,0.5,1.0$, 2.0, 4.0, 8.0 and $12 \mu \mathrm{M} \mathrm{DHQ}$ for $48 \mathrm{~h}$ was followed by viability measurement. (C) Cell viability under an inverted microscope. ${ }^{*} P<0.05 ;{ }^{* *} p<0.02 ;{ }^{* * *} p<0.01$ vs untreated cells

\section{DHQ induced apoptosis in A2780 and OVCAR 3cells}

The effect of DHQ on apoptotic changes in the cells were assayed using flow cytometry (Figure 2). Treatment with $12 \mu \mathrm{M} D \mathrm{DHQ}$ for $48 \mathrm{~h}$ significantly increased apoptotic cell fractions in A2780 and OVCAR 3 cells, relative to control cells $(p<0.05)$. In A2780 cells, treatment with 12 $\mu \mathrm{M} D \mathrm{DHQ}$ for $48 \mathrm{~h}$ resulted in $69.34 \%$ apoptosis, relative to $2.14 \%$ apoptosis in control cells. Similarly, treatment of OVCAR-3 cells with $12 \mu \mathrm{M}$ $\mathrm{DHQ}$ for $48 \mathrm{~h}$ produced $65.46 \%$ apoptosis, which was significantly higher than $1.78 \%$ apoptosis in control cells. 


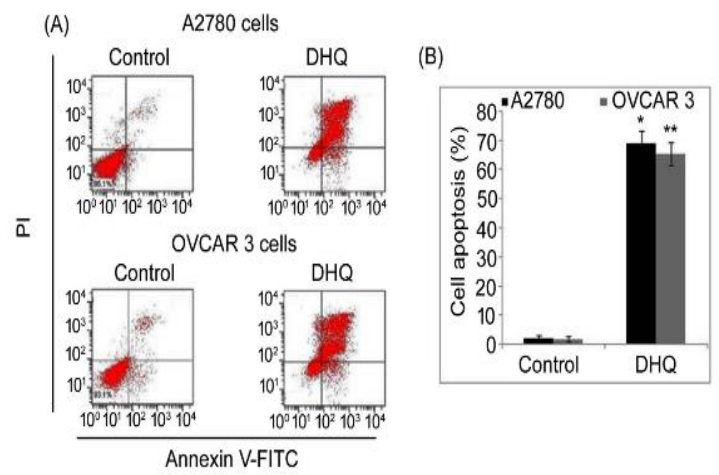

Figure 2: Effect of $D H Q$ on apoptosis of $A 2780$ and OVCAR 3 cells. Treated and untreated cells were analyzed for apoptosis at $48 \mathrm{~h}$ after Annexin V-FITC/PI staining using flow cytometry. ${ }^{*} P<0.02 ;{ }^{* *} p<0.01$, vs untreated cells

\section{DHQ inhibited cell migration}

The effect of $\mathrm{DHQ}$ on cell migration was determined using wound healing assay. As shown in Figure 3, the migratory potential of the cells was significantly decreased by treatment with $12 \mu \mathrm{M} \mathrm{DHQ}$, when compared with untreated cells. In A2780 cells, treatment with $12 \mu \mathrm{M} \mathrm{DHQ}$ decreased the migrating ability to $21.56 \%$, relative to $98.34 \%$ in untreated control. The DHQ treatment also suppressed OVCAR 3 cell migrating ability to $23.87 \%$, relative to $98.21 \%$ in untreated cells.

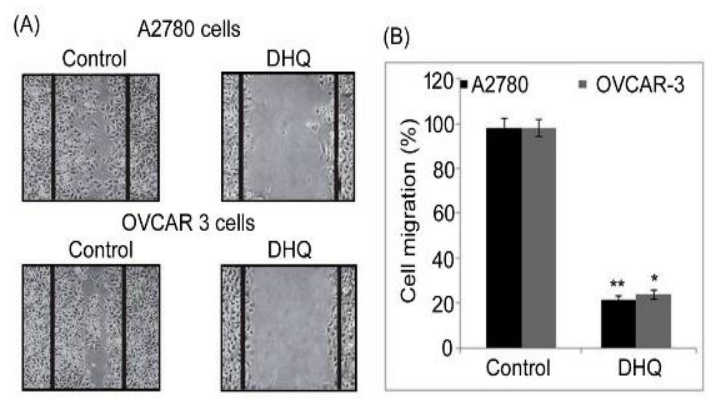

Figure 3: Effect of $\mathrm{DHQ}$ on migrating ability of the cells. The cell migration abilities of A2780 and OVCAR 3 cells treated with $12 \mu \mathrm{M} D H Q$ were determined with light microscopy. ${ }^{*} P<0.02 ;{ }^{* *} p<0.01$ vs. untreated cells. Magnification, $\mathrm{x} 250$

\section{DHQ suppressed cell invasiveness}

Wound healing assay was used to determine the effect of DHQ on cell invasive abilities. As shown in Figure 4, the invasiveness of cells treated with $12 \mu \mathrm{M} \mathrm{DHQ}$ was significantly decreased, when compared to untreated cells. In A2780 cells, treatment with $12 \mu \mathrm{M} \mathrm{DHQ}$ decreased invasive ability to $28.22 \%$, relative to $97.98 \%$ for untreated control. Similarly, the $12 \mu \mathrm{M} \mathrm{DHQ}$ treatment suppressed OVCAR 3 cell migrating ability to $29.88 \%$, relative to $99.10 \%$ for untreated cells.
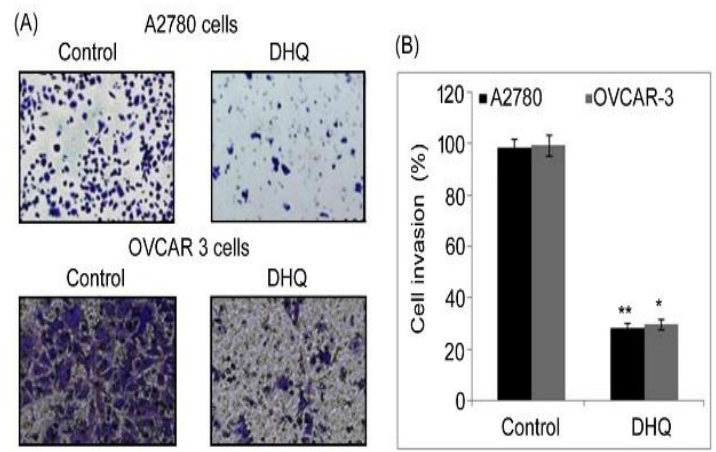

Figure 4: Effect of DHQ on invasiveness of the cells. Cell invasion potential of $A 2780$ and OVCAR 3 cells on treatment with12 $\mu \mathrm{M} \mathrm{DHQ}$ were assayed using Transwell chambers. ${ }^{*} P<0.02 ;{ }^{* *} p<0.01$ vs. untreated cells. Magnification, $\mathrm{x} 250$

\section{DHQ caused arrest of cell cycleatG1/G0 phase}

The effect of DHQ on the cell cycle was determined using flow cytometry (Figure 5). Treatment of the cells with $12 \mu \mathrm{M} \mathrm{DHQ}$ significantly enhanced the population of cells at the $\mathrm{G} 1 / \mathrm{G} 0$ phase, relative to untreated cells. There were significant reductions in cell content at the $S$ and G2/M phases in A2780 and OVCAR 3 cells treated with $12 \mu \mathrm{M} D H Q$ for $48 \mathrm{~h}$. Thus, $\mathrm{DHQ}$ treatment caused arrest of cell cycle at the G1/G0 phase.
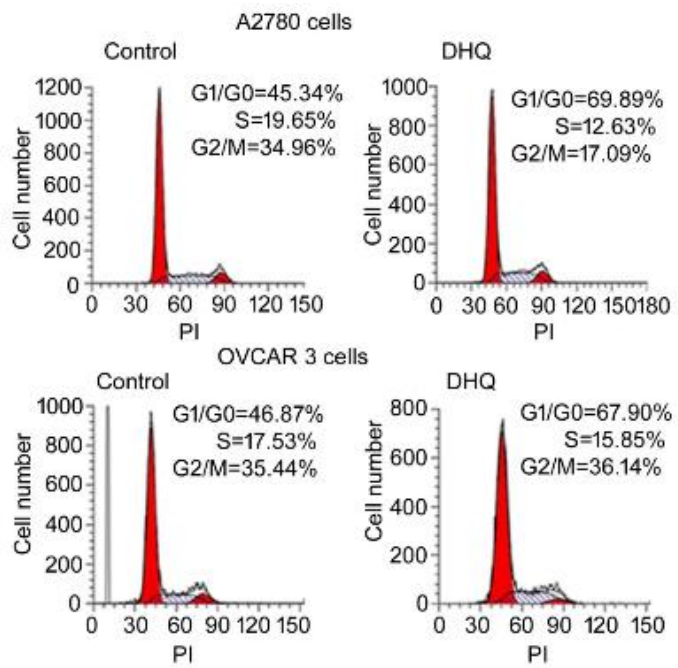

Figure 5: Effect of DHQ on the cell cycle. Cells treated with $12 \mu \mathrm{M} \mathrm{DHQ}$ and untreated controls were analyzed for changes in cellular DNA contents using flow cytometry after PI staining 
DHQ suppressed the expression of Wip1 in A2780 and OVCAR cells

The expression of Wip1 was markedly downregulated in the cells by treatment with $12 \mu \mathrm{M}$ DHQ (Figure 6). In DHQ-treated cells, markedly lower Wip1 mRNA expression, relative to control cells was observed. The DHQ-mediated suppression of Wip1 protein expressions in A2780 and OVCAR 3 cells were also confirmed using western blotting.

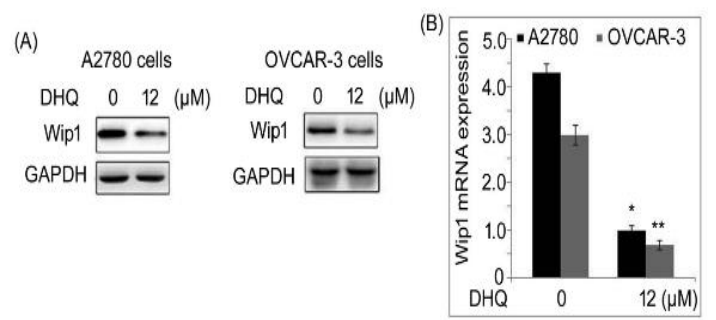

Figure 6: Effect of DHQ on Wip1 expression in the cells. (A) Cells treated with $12 \mu \mathrm{M} \mathrm{DHQ}$ and untreated cells were analyzed for Wip1 mRNA expression. (B) Changes in Wip1 protein expression in untreated or 12 $\mu \mathrm{M}$ DHQ-treated cells, as assayed using Western blotting. ${ }^{*} P<0.02,{ }^{* *} p<0.01$ vs untreated cells

\section{DISCUSSION}

Cancer is a worldwide health problem that accounts for $13 \%$ of mortality globally [3]. It has been projected that mortalities associated with cancer will increase to13.2million by the year 2030, relative to about 7.5 million deaths at present [3]. Non-functional and damaged cells in multi-cellular organisms are removed via the apoptotic pathway [14]. Chemotherapeutic agents suppress carcinoma growth by inducing DNA damage, followed by activation of apoptosis [15]. Apoptotic cells undergo shrinkage in size, chromatin condensation, formation of blebs, and cleavage of DNA [14]. In the current study, DHQ exerted toxicity on ovary carcinoma cells in a dose-depending manner. The DHQ treatment significantly reduced cellular viabilities in the ovarian cancer cells, relative to untreated cells. The treatment enhanced apoptosis activation, which was evident in the higher apoptotic cellular fraction in DHQ-treated cells. Moreover, DHQ reduced the migratory and invasive abilities of the cells, relative to control cells.

The oncogene, Wip1 which was identified in the nineteenth century, has been investigated by various research groups with respect to its involvement in different cancers [16]. It deactivates multiple proteins which are key components of DNA damage repair pathways [17]. The deactivation of some of these proteins, for example check point kinase-1, p53 and p16, causes tumorigenesis [17]. Thus, Wip1 is the negative regulator of DNA damage repair pathway, and an inducer of tumorigenesis [17]. In contrast, p53 is a tumor suppressor factor actively involved in repair of DNA damage via regulation of cellular apoptosis [18]. Thus, p53 dysfunction increases the resistance of tumors to therapeutic agents [19]. Studies have revealed that Wip1 mediated inhibition of p53 protein either by direct dephosphorylation or via inactivation of p38, MAPK and Mdm2 [20, 21]. Thus, the regulation of Wip1 expression so as to restore p53 activity has therapeutic role in various cancers.

In many solid tumors such as hepatic cancer, nasopharyngeal carcinoma, pulmonary cancer and prostate carcinoma, poor prognosis is related to increased Wip1 expression [22, 23]. The present study revealed elevated expressions of Wip1 (mRNA and protein) in the ovarian cancer cells. However, DHQ treatment significantly down-regulated the RNA and protein expressions of Wip1 in A2780 and OVCAR 3 cells, relative to control.

\section{CONCLUSION}

The findings of this study have shown that $D H Q$ exerted cytotoxic effects on ovarian cancer cell growth via arrest of cell cycle and activation of apoptosis. Moreover, DHQ inhibits the migratory and invasive ability of A2780 and OVCAR 3 cells. DHQ-mediated cytotoxic effect occurs via a mechanism associated with down-regulation of mRNA and protein expressions of Wip1. Therefore, $D H Q$ has potentials for use in the treatment of ovarian cancer.

\section{DECLARATIONS}

\section{Conflict of interest}

No conflict of interest is associated with this work.

\section{Contribution of authors}

We declare that this work was done by the author(s) named in this article and all liabilities pertaining to claims relating to the content of this article will be borne by the authors. Han Qi conceived and designed the study; Rao Zhiwei, Xia Songbai collected and analyzed the data; Rao Zhiwei, Han Qiwrote the manuscript. All authors read and approved the manuscript for publication. 


\section{Open Access}

This is an Open Access article that uses a funding model which does not charge readers or their institutions for access and distributed under the terms of the Creative Commons Attribution License (http://creativecommons.org/licenses/by/ 4.0) and the Budapest Open Access Initiative (http://www.budapestopenaccessinitiative.org/rea d), which permit unrestricted use, distribution, and reproduction in any medium, provided the original work is properly credited.

\section{REFERENCES}

1. Siegel RL, Miller KD, Jemal A. Cancer statistics, 2016. CA Cancer J Clin 2016; 66: 7-30.

2. Davis A, Tinker AV, Friedlander M. 'Platinum resistant' ovarian cancer: What is it, who to treat and how to measure benefit? Gynecol Oncol 2014; 133: 624-631.

3. Jemal A, Siegel R, Xu J, Ward E. Cancer statistics, 2010. CA Cancer J Clin 2010; 60: 277-300.

4. Kurman RJ, Shih leM. The origin and pathogenesis of epithelial ovarian cancer: A proposed unifying theory. Am J Surg Pathol 2010; 34: 433-443.

5. Agarwal R, Kaye SB. Ovarian cancer: Strategies for overcoming resistance to chemotherapy. Nat Rev Cancer 2003; 3: 502-516.

6. Mellor HR, Ferguson DJ, Callaghan R. A model of quiescent tumour microregions for evaluating multicellular resistance to chemotherapeutic drugs. $\mathrm{Br} \mathrm{J}$ Cancer 2005; 93: 302-309.

7. Fiscella $M$, Zhang $H$, Fan $S$, Sakaguchi $K$, Shen $S$, Mercer WE, Vande Woude GF, O'Connor PM, Appella E. Wip1, a novel human protein phosphatase that is induced in response to ionizing radiation in a p53dependent manner. Proc Natl Acad Sci USA 1997; 94. 6048-6053.

8. Zhang $L$, Chen $L H$, Wan $H$, Yang $R$, Wang $Z$, Feng $J$, Yang S, Jones S, Wang S, Zhou W, et al. Exome sequencing identifies somatic gain-of-function PPM1D mutations in brainstem gliomas. Nat Genet 2014; 46: 726-730.

9. Richter $M$, Dayaram $T$, Gilmartin AG, Ganji $G$, Pemmasani SK, Van Der Key $H$, Shohet JM, Donehower LA, Kumar R. Wip1 phosphatase as a potential therapeutic target in neuroblastoma. PLoS One 2015;10: e0115635.

10. Medici S, Peana M, Nurchi VM, Lachowicz JI, Crisponi G, Zoroddu MA. Noble metals in medicine: latest advances. Coord. Chem. Rev. 2015; 284: 329-350.

11. Monroe JD, Hruska HL, Ruggles HK, Williams KM, Smith1 ME. Anti-cancer characteristics and ototoxicity of platinum(II) amine complexes with only one leaving ligand. PLoS ONE 2018; 13: e0192505.
12. Chen ZF, Qin QP, Qin JL, Zhou J, Li YL, Li N, Liu YC, Liang $H$. Water-soluble ruthenium(II) complexes with chiral 4-(2, 3-dihydroxypropyl)-formamide oxoaporphine (FOA): in vitro and in vivo anticancer activity by stabilization of G-Quadruplex DNA, inhibition of telomerase activity, and induction of tumor cell apoptosis. J. Med. Chem. 2015; 58: 4771-4789.

13. Wang $Y$, Pang W, Zeng $Q$, Deng Z, Fan T, Jiang J, Deng $H$, Song $D$. Synthesis and biological evaluation of new berberine derivatives as cancer immunotherapy agents through targeting IDO1. Eur. J. Med. Chem. 2018; 143: 1858-1868.

14. Green DR (ed). Means to an End: Apoptosis and Other Cell Death Mechanisms. Cold Spring Harbor Laboratory Press, Long Island, NY, 2011.

15. Fulda S, Debatin KM. Targeting apoptosis pathways in cancer therapy. Curr Cancer Drug Targets 2004; 4: 569576.

16. Fujimoto $H$, Onishi $N$, Kato $N$, Takekawa $M, X u X Z$, Kosugi A, Kondo T, Imamura M, Oishi I, Yoda A, Minami $Y$. Regulation of the antioncogenic Chk2 kinase by the oncogenic Wip1 phosphatase. Cell Death Differ 2006; 13: $1170-1180$.

17. Lowe J, Cha H, Lee MO, Mazur SJ, Appella E, Fornace AJ Jr. Regulation of the Wip1 phosphatase and its effects on the stress response. Front Biosci (Landmark Ed) 2012; 17: 1480-1498.

18. Marcel V, Dichtel-Danjoy ML, Sagne C, Hafsi $H$, Ma $D$, Ortiz-Cuaran S, Olivier M, Hall J, Mollereau B, Hainaut $P$, Bourdon JC. Biological functions of p53 isoforms through evolution: Lessons from animal and cellular models. Cell Death Differ 2011; 18: 1815-1824.

19. Pfister C, Flaman JM, Dunet F, Grise P, Frebourg T. p53 mutations in bladder tumors inactivate the transactivation of the p21 and Bax genes, and have a predictive value for the clinical outcome after bacillus Calmette-Guerin therapy. J Urol 1999; 162: 69-73.

20. Crescenzi E, Raia Z, Pacifico F, Mellone S, Moscato F, Palumbo G, Leonardi A. Down-regulation of wild-type p53-induced phosphatase 1 (Wip1) plays a critical role in regulating several p53-dependent functions in premature senescent tumor cells. J Biol Chem 2013; 288: 16212-16224.

21. Lu X, Ma O, Nguyen TA, Jones SN, Oren M, Donehower LA. The Wip1 phosphatase acts as a gatekeeper in the p53-Mdm2 autoregulatory loop. Cancer Cell 2007; 12: 342-354.

22. Jiao L, Shen D, Liu G, Jia J, Geng J, Wang $H$, Sun Y. PPM1D as a novel biomarker for prostate cancer after radical prostatectomy. Anticancer Res 2014; 34: 2919 2925.

23. Satoh $N$, Maniwa $Y$, Bermudez VP, Nishimura K, Nishio W, Yoshimura M, Okita Y, Ohbayashi C, Hurwitz J, Hayashi Y. Oncogenic phosphatase Wip1 is a novel prognostic marker for lung adenocarcinoma patients survival. Cancer Sci 2011; 102: 1101-1106. 